International Journal of Current Microbiology and Applied Sciences

ISSN: 2319-7706 Volume 10 Number 12 (2021)

Journal homepage: http://www.ijcmas.com

\title{
Assessment of the Sanitary Quality of the Dishes Sold in Street's Restaurants with High Frequentation in Daloa (Ivory Coast)
}

\author{
Yao Paul ATTIEN ${ }^{1,2 *}$, Arthur Constant ZEBRE ${ }^{1}$, Haziz SINA ${ }^{2}$, \\ Djédoux Maxime ANGAMAN ${ }^{1}$, Lamine BABA MOUSSA ${ }^{2}$ and Adjehi T. DADIE ${ }^{1}$
}

${ }^{1}$ Biochemistry-Microbiology Department, Agrovalorisation Laboratory, Jean LorougnonGuede University, BP 150, Daloa, Côte d'Tvoire

${ }^{2}$ Laboratory Biology and Typing Molecular in Microbiology, Faculty of Science and Technology, University of Abomey-Calavi, 05 BP 1604 Cotonou, Benin

*Corresponding author

\section{A B S T R A C T}

\section{Keywords}

Street's restaurants,

Food sanitary,

Pathogenic bacteria,

Daloa

Article Info

Received:

05 November 2021

Accepted:

04 December 2021

Available Online:

10 December 2021
The hygiene and quality of food sold in restaurants have a strong impact on the health of the consumer. It is with this in mind that this study was carried out to assess the sanitary quality of the dishes sold in restaurants with high frequentation in the city of Daloa (Ivory Coast). As a prelude to this study, a survey was carried out to find out the areas of high frequentation of restaurants, the socio-demographic profile of crews and customers. And finally, an evaluation of the microbiological quality of some dishes which made it possible to search for germs such as GAM, E. coli, S. aureus and Salmonella $s p$. The results obtained showed that the restaurant business is carried out by women $(100 \%)$ aged between 19 and 29 years (57.5\%) with a low level of education (55\%). Many were single (55\%) whose length of service in the trade varied between 1 and 5 years (65\%). Most of the consumers were men (59.2\%) and single (69.7\%). Microbiological analysis of the dishes sold showed contamination by GAM $\left(10^{3}\right.$ to $\left.10^{6} \mathrm{CFU} / \mathrm{g}\right)$, E. coli $\left(10^{2}\right.$ to $\left.10^{5} \mathrm{CFU} / \mathrm{g}\right)$, S. aureus $\left(3.10^{3}\right.$ to $\left.2.10^{5} \mathrm{CFU} / \mathrm{g}\right)$ and presence of Salmonella sp. According to the standard, it appears that $42 \%$ of the dishes had an acceptable microbiological quality, $16 \%$ satisfactory and $42 \%$ of unsatisfactory quality. The non-observance of good hygiene practices in restaurants is one of the causes of microbial contamination of dishes.

\section{Introduction}

Street food is defined by the Food and Agriculture Organization (FAO) as "ready-toeat foods and beverages sold and prepared by vendors or hawkers in streets or other public places (Lamuka, 2014). In both developed and underdeveloped countries, this sector is expanding, presenting a real opportunity for employment and source of income (Rheinländer et al., 2008, Muyanja et al., 2011; Ma et al., 2019; Ssegueya et al., 2020). 
This is due to industrialization which forces many city dwellers to take their main daily meals away from home (Alimi et al., 2014, Nizame et al., 2019). It is also a place to eat for low-income households (Nizame et al., 2020). Due to their rapid availability, foods sold in street restaurants are one of the main food options for city dwellers (Zubaer and Sabiha, 2019). However, the consumption of the dishes sold in the various restaurants is not without consequences for the health of consumers. Indeed, these street restaurants are the sources of many foods poisoning (Nasrolahei et al., 2017; Zubaer and Sabiha, 2019; Khomotso et al., 2020). Numerous cases of toxi infection have been reported around the world. According to the World Health Organization (WHO), each year about 600 million people contract a food-borne illness in which 420,000 die (WHO, 2015). In the US, foodborne illness affects more than 48 million people each year, resulting in 128,000 hospitalizations and 3,000 deaths (CDC, 2017). Both Africa and Southeast Asia have the highest incidence and mortality rates associated with foodborne illness (WHO, 2015; Adane et al., 2018). In Côte d'Ivoire, many cases of food poisoning have been identified in several towns over the past decades. The most recent case occurred in Bingerville (Abidjan) in 2019 where 34 cases of foodborne illness were reported (APA News, 2019). Most foodborne illness outbreaks are usually caused by poor hygiene in food restaurants and vendors (Todd et al., 2008: Chukuezi, 2010: Khomotso et al., 2020). The aim of this study is therefore to assess the level of hygiene and the sanitary quality of the dishes sold in restaurants with high attendance in the city of Daloa. Indeed, in this city to date there is no scientific information on the hygiene of restaurants hence the interest of this study. To this end, a socio-demographic survey was carried out among restaurateurs and consumers, which made it possible to assess their knowledge of good hygiene practices. To find the criteria for assessing the quality of ready meals, microbiological analyzes were carried out.

\section{Materials and Methods}

\section{Study area description}

The study was carried out in the town of Daloa. Located in the Center-West of Côte d'Ivoire. Chief town of Haut-Sassandra department and region. Daloa is located 141 $\mathrm{km}$ from Yamoussoukro the political capital and $383 \mathrm{~km}$ from Abidjan the economic capital. Geographically, Daloa is located at $6^{\circ}$ 53-north latitude and $6^{\circ}$ 27-west longitude. Daloa is an urban center with a population of 245,362 inhabitants (RGPH, 2014, personal communication 2014). She is the $3^{\text {rd }}$ largest city in terms of population after Abidjan and Bouake in Côte d'Ivoire. The municipality covers an area of $5305 \mathrm{~km} 2$ with a density of 50,141 inhabitants / $\mathrm{km} 2$ and it has 45 neighborhoods (Tchehi, 2021)

\section{Data collection}

This study consisted, first of conducting a survey based on questionnaires and observations in restaurants in Tazibouo, Commerce and Lobia, 3 districts of Daloa. Then an exchange based on a pre-established questionnaire was carried out with restaurant owners and consumers. The questionnaire concerning restaurateurs aims to provide information on socio-demographic characteristics (sex, age, ethnic group educational level, experience, type of dish sold), places of supply of raw material, conservation of non-food sold, the importance of hygiene. The questionnaire concerning consumers in addition to providing information on socio-demographic characteristics provides the following information: the preference of the dish, the appreciation of the hygiene of the premises 
and the staff and the sanitary quality of the dishes consumed (type discomfort after consumption: diarrhea, fever, vomiting). Following the results of the surveys, two restaurants were chosen in each district (a total of 6 restaurants). In each restaurant, 8 samples of dishes were taken in 3 times that done 144 dishes in total. All samples were collected by purchase from the six (6) restaurants. They consist of hot lunch meals. These samples weigh approximately $500 \mathrm{~g}$. They were placed in sterile containers and transported in a cooler containing cold accumulators to the Agrovalorisation laboratory at Jean Lorougnon Guede University to perform microbiological analyzes. The following germs were searched: Mesophilic aerobic germs, Escherichia coli, Staphylococcus aureus, Fungal flora, and Salmonella spp.

\section{Bacteria isolation and identification}

The following germs: Fungal flora, Mesophilic aerobic germs, Escherichia coli, Staphylococcus aureus and Salmonella were looked for in. The specific culture media (see table below) for each germ were prepared according to the manufacturer's recommendations.

\section{Sample analysis}

Samples weighing $25 \mathrm{~g}$, were homogenized in a stomacher lab-blender 400 (Seward, London, England) with buffered peptone water (AES Laboratory, Combourg, France) in 1:10 sample / broth ratio at $37 \mathrm{C}$ for $1 \mathrm{~h}$. From this suspension, a series of decimal dilutions is then carried out. Two types of inoculation were carried out during this manipulation. This is the mass seeding which concerned the chromogenic E. coli media, PCA, the surface seeding by spreading which considered the Sabouraud media with Chloramphenicol, Baird Parker the surface seeding by streak which concerns the Hektoen medium for the detection of salmonella. The dishes thus solidified were incubated at room temperature for 7 days for the enumerations of yeasts and molds, at $37^{\circ} \mathrm{C}$ for 72 hours for the aerobic mesophilic germs and $24 \mathrm{~h}$ for the Staphylococcus aureus cells and finally at $44^{\circ}$ C for 24 hours for the E.coli sprouts.

Identification of strains of $E$. coli, Salmonella sp and S. aureus

Presumptive colonies of E. coli, Salmonella and $S$. aureus were purified on plain agar followed by Gram stain and Le Minor reduced rack. Then, the following biochemical tests were carried out on the various presumptive colonies: catalase test, urea-indole test, Use of citrate, Kliger-Hajna medium, iron lysine test and the mobility test.

\section{Colony enumeration}

Colony forming units per milliliter of sample (CFU / g) were calculated according to standard NF / ISO 7218: 2007 using the following formula:

$$
\mathrm{N}=\frac{\sum \mathrm{C}}{\mathrm{Vx}\left(\mathrm{n}_{1}+0,1 \times \mathrm{n}_{2}\right) \mathrm{xd}}
$$

where $\Sigma \mathrm{C}$ : sum of characteristic colonies counted on all retained Petri dishes; n1: number of Petri dishes retained at the first dilution; $\mathrm{n} 2$ : number of Petri dishes retained at the second dilution; $\mathrm{d}$ : dilution rate corresponding to the first dilution; V: inoculated volume $(\mathrm{mL}) ; \mathrm{N}$ : number of microorganisms (CFU / g).

Criterion for assessing the quality of prepared meals

The results obtained after microbiological analysis are compared with the reference criteria to assess the wholesomeness of the 
cooked meals. The criteria for assessing the various parameters sought are mentioned in Table I below.

Interpretation of the three-class plan:m:Minimum threshold of the number of germs present in a gram of product analyzed, result found to be less than or equal to $\mathrm{m}$, the microbiological quality of the product is considered satisfactory. M:Maximum threshold of the number of germs present in one gram of product analyzed; above which the microbiological quality of the product is considered Unsatisfactory. Results found between $\mathrm{m}$ and $\mathrm{M}$, Acceptable microbiological quality

\section{Statistical analysis}

All trials were repeated 3 times, Data were fed to the computer and analyzed using IBM SPSS software package, version 20.0 (IBM Corp, Armonk, New York, USA). The Kolmogorov-Smirnov, Shapiro, and D'agstino tests were used to verify the normality of distribution of variables. Comparisons between groups for categorical variables were assessed using $\chi 2$-test.

Kruskal-Wallis test was used to compare different groups for abnormally distributed quantitative variables and followed by posthoc test (Dunn's multiple comparisons test) for pair wise comparison. Significance of the obtained results was judged at the $5 \%$ level.

\section{Results and Discussion}

Consumers eating place in the neighborhoods of Daloa city

The results of the survey (Figure) showed that the Tazibouo (29,5\%), Commerce $(22,5 \%)$, Lobia $(8,5 \%)$ and Soleil $(6,5 \%)$ districts are the preferred places to eat. The Marrais district is the least frequented by consumers questioned during the survey. They are less than $0,5 \%$.

Sociodemographic characteristics of restaurateurs

The results of the analysis (Table) show that most respondents are women $(100 \%)$, of whom $57.5 \%$ are aged between 19 and 29 years, $22.5 \%$ are aged between 30 and 40 years and $20 \%$ are over 40 years. As for their level of education, $21.5 \%$ are illiterate, $55 \%$ have primary school level and $23.5 \%$ have secondary level. Regarding the marital situation, they are 55\% single, $22 \%$ in a couple and $22.5 \%$ married. As regards seniority in the restaurant business, $65 \%$ of women have one year of experience between 1 to 5 years and $35 \%$ have one year of experience between 6 to 10 years.

\section{Classification of the most sold or most consumed dishes or dishes in restaurants}

The figure (2) shows the proportion of the most sold dishes in the different restaurants. The dishes "Riz sauce graine" (22\%) and "Riz sauce aubergine" (20\%) are the most sold. The other dishes, namely Foutousauce aubergine, Foutou sauce graine, Placali sauce graine and "Tchèp" represent respectively 18\%, 10\%, $12 \%$ and $13 \%$ of the sale.

Location and assessment of the level of hygiene in restaurants by investigators

According to the results of the surveys on 40 restaurants, most restaurants $(88.33 \%)$ are located far from the approaches to main roads, gutters, and garbage dumps. A guided tour of the various restaurants made it possible to appreciate the level of hygiene. The elements of assessment are as follows: presence of a device for washing hands, toilet, protected cover, drinking water for washing dishes (constantly renewed), state of clothing (clean 
or dirty) of employees. The observations made show that most of the restaurants have a hand washing device $(80 \%)$ and a toilet $(87 \%)$. The unprotected dishes observed were $80 \%$ and the dishwater not renewed was $72.5 \%$.

\section{Sociodemographic characteristics of consumers}

The results obtained after analyzing the sociodemographic characteristics of consumers. (200 people) are recorded in the tables. They reveal that a large majority of people who frequent restaurants were between 18 and 39 years old, a rate of $91 \%$ against a rate of $9 \%$ for people over 40 years old. In terms of education, respondents had a secondary level with a rate of $45.8 \%$ against a rate of $38.8 \%$ for the higher level, $10.4 \%$ for the primary level and $4.5 \%$ for the level. illiterate. Regarding the sex of the respondents, the results show that $59.2 \%$ were men against $40.8 \%$ women. As for the marital situation, $69.7 \%$ were single against a rate of $19.9 \%$ as a couple, $8 \%$ married, $0.5 \%$ divorced and $1.5 \%$ were widowed.

\section{Types of symptoms after eating dishes in restaurants}

Analyzes show that the following symptoms: Vomiting, diarrhea and stomach bloating are usually seen after eating food in restaurants. Among people surveyed out of a total of 200 people, $68 \%$ of consumers suffered from diarrhea, $16 \%$ from vomiting and $16 \%$ from stomach bloating.

\section{Microbiological analysis of dishes sold in restaurants}

The microbiological analysis of the 144 samples made it possible to highlight the contamination of the latter by the microbial flora and the fungal flora (yeasts and molds). In terms of the microbial flora, the following germs: GAM, E.coli, S. aureus and Salmonella $s p$ were enumerated. The table below shows the count of the suspected colonies gave a load which varied from $10^{2}$ to $2.10^{5} \mathrm{CFU} / \mathrm{g}$ for S. aureus; a load of $10^{2}$ to 6 . $10^{3} \mathrm{CFU} / \mathrm{g}$ for $E$. coli, a load ranging from $10^{3}$ to $7.10^{4} \mathrm{CFU} / \mathrm{g}$ for the fungal flora, a load of $4.10^{3}$ to $5.10^{5} \mathrm{CFU} / \mathrm{g}$ for aerobic mesophilic germs and a presence of salmonella sp. The count of the suspected colonies gave average loads recorded in the table below. The comparison of the enumeration results with the pre-established standard made it possible to assess the sanitary quality of the different samples. On the 144 samples, $41.7 \%$ of samples were of unsatisfactory microbiological quality. Two $16.7 \%$ of samples were satisfactory microbiological quality of samples) and 41, $7 \%$ of samples were of acceptable microbiological quality,

As the consumption of meals away from home is a reality in the city of Daloa, we undertook this study to know the socio-demographic characteristics of restaurateurs and consumers and to assess the health quality of certain dishes sold. At the restaurant owner level, the results obtained show that this activity is mainly carried out by women $(100 \%)$, whose age varies between 19 and 40 years (80\%).

They were mostly single (55\%) with a primary education level $(55 \%)$. Our results on the gender of restaurateurs are consistent with those carried out by Monney et al., (2014) in Ghana which showed that street restaurants were more than $95 \%$ run by women. This activity is in general in many countries such as Ghana (Apanga et al., 2014), Nigeria (Chukuezi et al., 2010), Cameroon (Edima et $a l ., 2014$ ) and in South Africa (Khomotso et al., 2020) exercised by women. On the other hand, in other regions of Africa this activity is carried out by men. This is the case in Ethiopia (Adane et al., 2018). 
Table.1 Media used

\begin{tabular}{|c|l|}
\hline Germs wanted & \multicolumn{1}{c|}{ Culture media used } \\
\hline Fungal flora & Sabouraud with Chloramphenicol (ALPHA BIOSCIENCES) \\
\hline Aerobic Mesophilic Germs & Plate Count Agar (CONDA) \\
\hline Escherichia coli & Chromogenic E. coli(BIORAD group) \\
\hline Staphylococcus aureus & Baird Parker (Eur Pharm) \\
\hline Salmonella & Hektoen, (BIOSCIENCES) Rappaport de Vassiliadis(BIORAD) \\
\hline
\end{tabular}

Table.2 Quality assessment criteria cooked meals

\begin{tabular}{|c|c|c|c|}
\hline \multirow{2}{*}{ Germs } & \multicolumn{2}{|c|}{ Microbiological limit (cfu / g) } & \multirow{2}{*}{ References } \\
\cline { 2 - 3 } & $\mathrm{m}$ & $\mathrm{M}$ & \\
\hline Mesophilic Aerobic Germs (GAM) & $3.10^{5}$ & $3.10^{6}$ & Official Journal of the \\
\hline Escherichia coli & $10^{3}$ & $10^{4}$ & Republic of France of July 2, \\
Staphylococcus aureus & $10^{2}$ & $10^{3}$ & \\
\hline Fungal flora & $5.10^{2}$ & $5.10^{3}$ & \\
\hline Salmonella & Absence in 25 g of food & \\
\hline
\end{tabular}

Table.3 Sociodemographic characteristics of restaurateurs

\begin{tabular}{|c|c|c|c|}
\hline No. & Setting & Total & Frequencies \\
\hline \multirow[t]{4}{*}{1} & Sex & & \\
\hline & Women & 120 & $100 \%$ \\
\hline & Man & 00 & $0 \%$ \\
\hline & & 120 & $100 \%$ \\
\hline \multirow[t]{6}{*}{2} & Age & & \\
\hline & $<18$ & 0 & $0 \%$ \\
\hline & 19 to 29 years old & 69 & $57.5 \%$ \\
\hline & 30 to 40 years old & 27 & $22.5 \%$ \\
\hline & $>40$ years & 24 & $20 \%$ \\
\hline & & 120 & $100 \%$ \\
\hline \multirow[t]{6}{*}{3} & Study level & & \\
\hline & Illiterate & 24 & $21.5 \%$ \\
\hline & Primary & 66 & $55 \%$ \\
\hline & Secondary & 27 & $23.5 \%$ \\
\hline & University & 0 & $0 \%$ \\
\hline & & 120 & $100 \%$ \\
\hline \multirow[t]{7}{*}{4} & Marital status & & \\
\hline & Single & 66 & $55 \%$ \\
\hline & In a relationship (not Married) & 27 & $22.5 \%$ \\
\hline & Married & 27 & $22.5 \%$ \\
\hline & Divorced & 0 & $0 \%$ \\
\hline & Widow & 0 & $0 \%$ \\
\hline & & 120 & $100 \%$ \\
\hline \multirow[t]{4}{*}{5} & Seniority & & \\
\hline & 1 to 5 years & 78 & $65 \%$ \\
\hline & 6 to 10 years & 42 & $35 \%$ \\
\hline & & 120 & $100 \%$ \\
\hline
\end{tabular}


Table.4 Sociodemographic characteristics of consumers.

\begin{tabular}{|c|c|c|c|}
\hline No. & Parameter & Total & Frequencies \\
\hline $\mathbf{1}$ & Age & 19 & $9.5 \%$ \\
\hline & $<18$ years & 129 & $64.5 \%$ \\
\hline & 19 to 29 years old & 34 & $17 \%$ \\
\hline & 30 to 39 years old & 18 & $9 \%$ \\
\hline & $>40$ years & $\mathbf{2 0 0}$ & $\mathbf{1 0 0 \%}$ \\
\hline $\mathbf{2}$ & Educational level & 9 & $4.5 \%$ \\
\hline & Illiterate & 21 & $10.4 \%$ \\
\hline & Primary & 92 & $45.8 \%$ \\
\hline & Secondary & 78 & $38.8 \%$ \\
\hline & University & $\mathbf{2 0 0}$ & $\mathbf{1 0 0 \%}$ \\
\hline & & 119 & $59.2 \%$ \\
\hline $\mathbf{3}$ & Sex & 81 & $40.8 \%$ \\
\hline & Man & $\mathbf{2 0 0}$ & $\mathbf{1 0 0 \%}$ \\
\hline & Women & 140 & $69.7 \%$ \\
\hline $\mathbf{4}$ & Marital status & 40 & $19.9 \%$ \\
\hline & Single & 16 & $8 \%$ \\
\hline & Married & 1 & $0.5 \%$ \\
\hline & In a relationship (not Married) & 3 & $1.5 \%$ \\
\hline & Widow & $\mathbf{2 0 0}$ & $\mathbf{1 0 0 \%}$ \\
\hline & & & \\
\hline & & & \\
\hline
\end{tabular}

Table.5 Microbiological analysis of different dishes

\begin{tabular}{|c|c|c|c|c|c|}
\hline Type of dishes analyzed & \multicolumn{5}{|c|}{ Germs } \\
\cline { 2 - 6 } & GAM & E.coli & S. aureus & Fungal flora & Salmonella $s p$ \\
\hline Riz sauce graine & $2.10^{5} \pm 0.6$ & $1.10^{2} \pm 0.4$ & $2.10^{4} \pm 0.7$ & $5.10^{3} \pm 0.1$ & Absent \\
\hline Riz sauce arachide & $2.10^{5} \pm 0.3$ & $9.10^{2} \pm 0.3$ & $10^{4} \pm 0.2$ & $1.10^{3} \pm 0.5$ & Absent \\
\hline Riz sauce aubergine & $4.10^{3} \pm 0.2$ & $1.10^{3} \pm 0.2$ & $2.10^{4} \pm 0.3$ & $2.10^{3} \pm 0.6$ & Absent \\
\hline Foutou sauce graine & $5.10^{5} \pm 0.3$ & $3.10^{3} \pm 0.2$ & $2.10^{5} \pm 0.5$ & $4.10^{4} \pm 0.4$ & Absent \\
\hline Foutou sauce aubergine & $4.10^{5} \pm 0.8$ & $6.10^{3} \pm 0.4$ & $2.10^{5} \pm 0.2$ & $7.10^{4} \pm 0.1$ & Presence \\
\hline Foufou sauce clair & $5.10^{4} \pm 0.5$ & $2.10^{3} \pm 0.4$ & $3.10^{4} \pm 0.1$ & $5.10^{4} \pm 0.3$ & Absent \\
\hline Placali sauce graine & $3.10^{5} \pm 0.2$ & $7.10^{2} \pm 0.3$ & $10^{4} \pm 0.3$ & $3.10^{3} \pm 0.4$ & Absent \\
\hline Tchep & $5.10^{5} \pm 0.3$ & $2.10^{2} \pm 0.3$ & $1.10^{2} \pm 0.4$ & $7.10^{3} \pm 0.6$ & Absent \\
\hline
\end{tabular}


Fig.1 Frequency of consumers by district

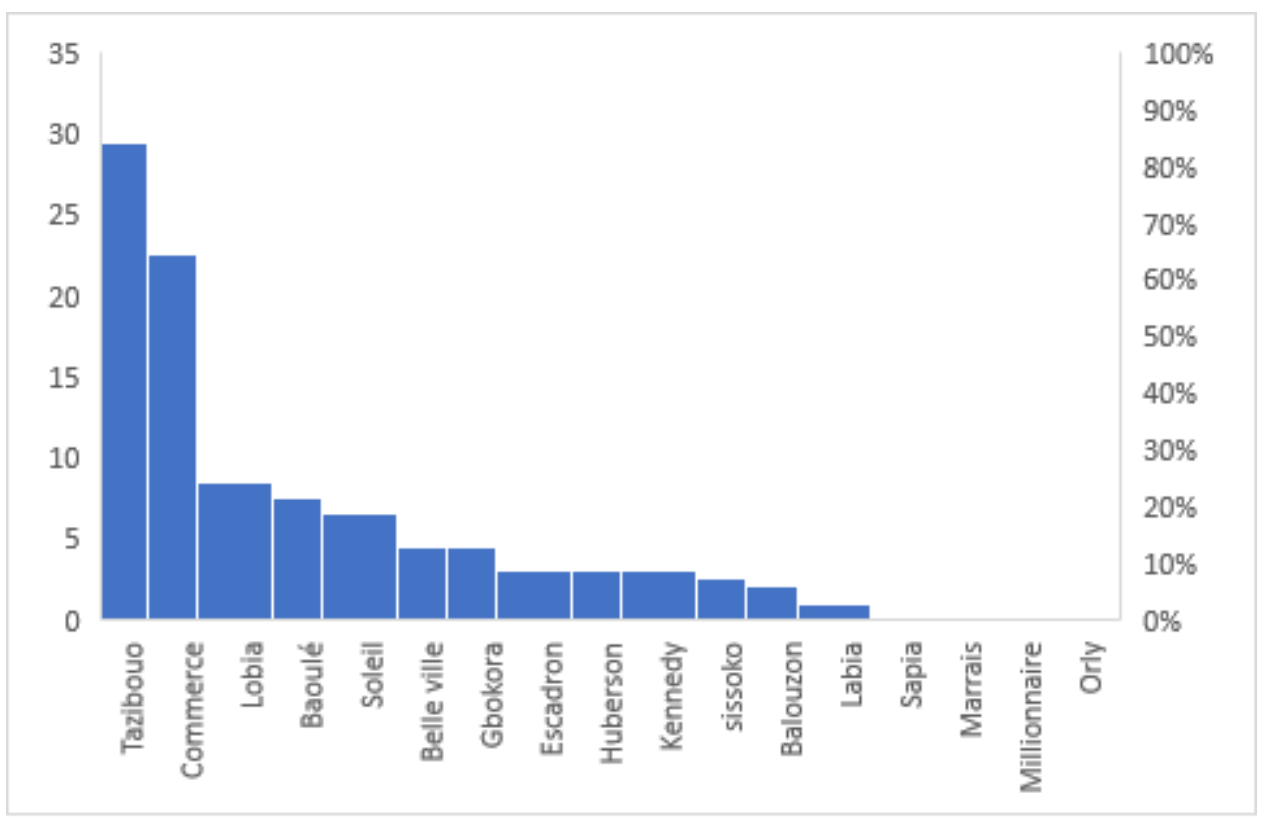

Fig.2 Frequency of dishes sold

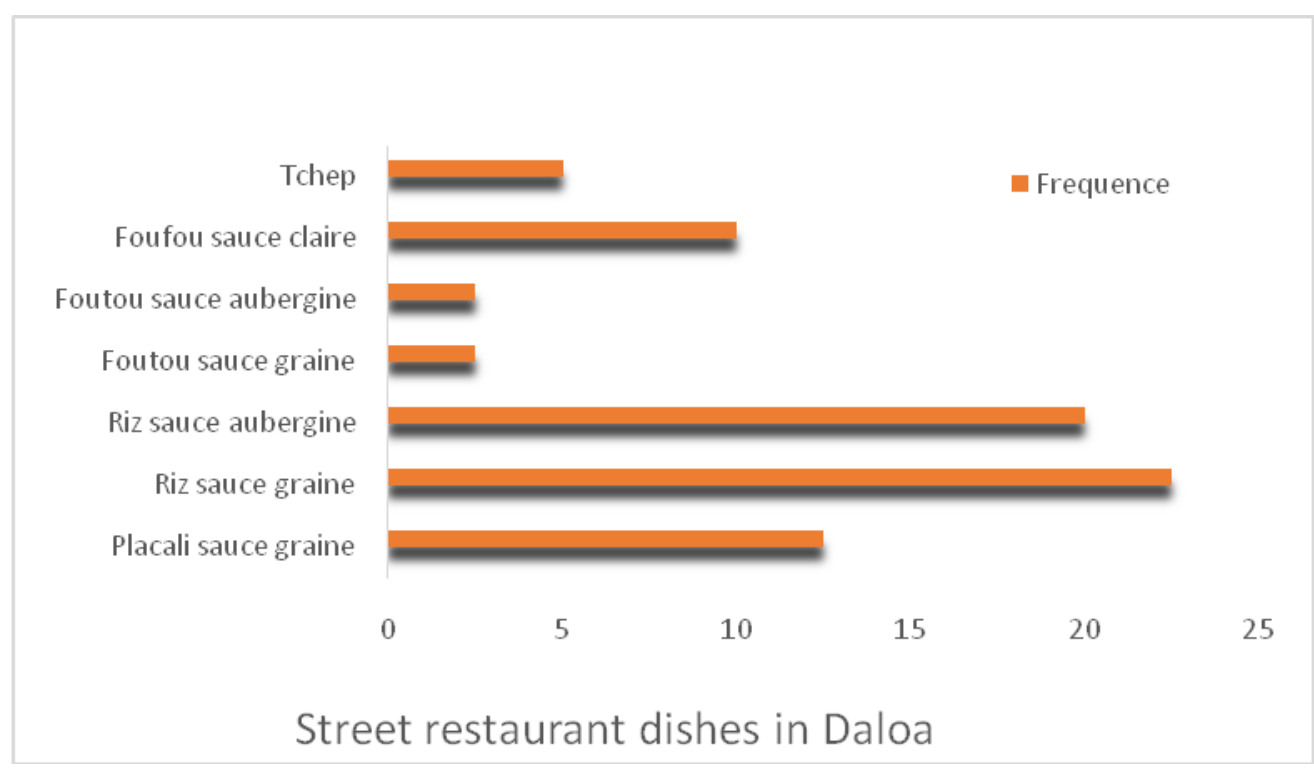

According to Monney et al., (2014), the assertion that the restaurant business in developing countries is a predominantly female trade may not be entirely true; it is rather according to the geographical area considered. The predominance of women in the restaurant sector in sub-Saharan Africa may be because they are the main breadwinners in most poor households (Khomotso et al., 2020). Regarding the 19 to 40 age group of which they are over $80 \%$ and mostly single, our results corroborate previous studies in this area in various African countries (Rahman et al., 2014). Indeed, this activity constitutes a source of income for the very poorly qualified and educated women 
(Khomotso et al., 2020). Contrary to the practice of catering exclusively by women in our study, consumers are both men (with a rate of $59.2 \%)$ and women $(40.8 \%$ among women), as also shown by study by Mensah $e t$ al., (2013) but with a proportion of $56.7 \%$ women and $43.3 \%$ men. In our study, the age of these different consumers was between 19 and 39 years, a rate of $91 \%$ against $9 \%$ of respondents who were over 40 years old. Many consumers are single $(69.7 \%)$ and have a high school education (45.8\%). While in most of the studies carried out, consumers are single (Mensah et al., 2013; Monnet et al., 2014: Fosiul et al., 2019; Khomotso et al., 2020). The level of education of our respondents differs from that found in the work of Mensah et al., 2013 in which consumers had no formal education (illiterate). This difference is the fact that Daloa is a university town with an enrollment rate of $99 \%$ of which $45 \%$ reach the secondary cycle (MENFPT, 2020). As for the hygienic assessment of the premises, it appears that the hygiene is rather acceptable, however, a lot of effort remains to be made to respect the level and importance of hygiene. Indeed, according to Adane et al., (2018), there needs to be continuous awareness of the importance of hygiene in these places. Indeed, this lack of hygiene leads to foodborne illnesses such as diarrhea, vomiting and stomach bloating contracted at least once by consumers. These diseases are usually caused by food pathogens (komotso et al., 2020). This observation is confirmed by the results of the analysis of certain dishes which revealed the presence of pathogens such as: Escherichia coli, salmonellasp, S. aureus, GAM, and fungi. The presence of these microorganisms makes it possible to assess the level of hygiene, the quality of food and the risk of food poisoning for consumers (Rosmini et al., 2004). If the microbial load of GAM respected the published standard on the other hand for certain dishes, the microbial load of E. coli and $S$. aureus were higher than the standard. Indeed, these microorganisms are hand carried, it denotes a lack of hygiene in some restaurants as observed during the various surveys.

The study revealed that the restaurant sector is predominantly carried out by women. The latter are young women and single in their great majority. The main customers frequenting these restaurants are young men with a high school education. Microbiological analysis of the dishes sold revealed the presence of pathogenic germs (E. coli, $S$. aureus, Salmonella and GAM). According to the applied standard, it emerged that $42 \%$ of the dishes had an acceptable quality, $16 \%$ satisfactory and $42 \%$ of unsatisfactory quality. The non-observance of good hygiene practices and the lack of hygiene in restaurants are one of the causes of microbial contamination.

\section{References}

Apanga S., Addah J, Danso R S (2014). Food Safety Knowledge and Practice of Street Food Vendors in Rural Northern Ghana. Food and Public Health 4 (3): 99-103.

CDC (2011). Estimates of Foodborne Illness in the United States. https://www.cdc.gov/foodborneburden/pdfs/F ACTSHEET_A_FINDINGS.pdf. Accessed 15 Feb 2017. 2011.

Chukuezi C O (2010). Food safety and hyienic practices of street food vendors in Owerri, Nigeria. Studies in Sociology of Science. 1 (1): 50-57.

Edima H C, Tem N R K, Awono E T., Biloa D. M., Ndjouenkeu R. (2014). Case Study of the Street Food Sector in the Metropolitan Areas of a Cameroonian City, Yaounde. Int. J. Curr. Microbiol. App.Sci. 3 (9) 740-751

Khomotso J. M., Chelule P K (2020). Safe Food Handling Knowledge and Practices of Street Food Vendors in Polokwane Central Business District. Foods. 9 (11): 1560.

Lamuka P O (2014). Public Health Measures: Challenges of Developing Countries in Management of Food Safety. In: Motarjemi 
Y. (ed.) Encyclopedia of Food Safety, Volume 4, pp. 20-26. Waltham, MA: Academic Press.

Ma L., Hong C., Huizhe Y., Lifeng W., Wenbin Z. (2019). Food safety knowledge, attitudes, and behavior of street food vendors and consumers in Handan, a third-tier city in China. BMC Public Health. 19: 1128 https://doi.org/10.1186/s12889-019-7475-9

Monney I., Agyei D., Badzi S., Campaore P., Nyaw S. (2014). Food hygiene and Safety Practices among Street Food Vendors: An Assessment of Compliance, Institutional and Legislative Framework in Ghana. Food and Public Health. 4 (6): 306-315 DOI: 10.5923 / j.fph.20140406.08

Muyanja, C., Nayiga, L., Brenda N., Nasinyama G (201)1. Practices, knowledge and risk factors of street food vendors in Uganda. Food Control, 22, 1551-1558

Nasrolahei M., Mirshafiee S., Kholdi S., Salehian M., Nasrolahei M. (2017). Bacterial assessment of food handlers in Sari city, Mazandaran Province, north of Iran. J Infect Public Health. 10: 171-176

Nizame F. A., Mahbub U A, Abdullah A M, Abul K S, Aftab O., Khairul I M, Luby $\mathrm{P} S$, Unicomb L. (2019). Hygiene in Restaurants and among Street Food Vendors in Bangladesh. Am. J. Trop. Med. Hyg. 101 (3), 566-575

Rahman M M, Arif M T, Bakar K., Talib Z. (2016). Food safety knowledge, attitude, and hygiene practices among the street food vendors in Northern Kuching City, Sarawak. Borneo Sci. 31, 95-103.

Rosmini M R, Signori M L, Schneider R., Bonazza J C (2004). Evaluation of two alternative techniques for counting mesophilic aerobic bacteria in raw milk. Food Control, 15 (1): 39-44.

Sseguya W, Matovu N, Swann N, Alizon Draper (2020). Contribution of street food to dietary intake of habitual urban consumers: A crosssectional study in Kampala city, Uganda. Nutr Health 26 (3): 187-195.

Tchehi Zananhi Florian Joël (2021). Socioeconomic problematic of aging in Daloa (center-west of Côte d'Ivoire). African Journal of Social Sciences and Public Health. 3 (1) : 110-123

Rheinländer T., Mette O., Bakang J. A, Harriet T., Flemming K., Helle S. (2008). Keeping Up Appearances: Perceptions of Street Food Safety in Urban Kumasi, Ghana. Journal of Urban Health: Bulletin of the New York Academy of Medicine. 85 (6) 952-964

Todd E C, Greig J D, Bartleson C A and Michaels B S (2008). Outbreaks where food workers have been implicated in the spread of foodborne disease. Part 5. Sources of contamination and pathogen excretion from infected persons. J Food Prot71: 2582-2595

WHO (2015).WHO's first ever global estimates of foodborne diseases find children under 5 account for almost one third of deaths, 3 December 2015.

WHO (2015). Report on global burden of foodborne disease. 2015.http: //www.ianphi.org/news/2015/foodborneillnes s.html. Accessed 16, June 2017. 2015.

Zubaer H. and Sabiha A. (2019.) Microbial Quality of Common Restaurant Foods: Food Safety Issue in Bangladesh. Journal of Food and Nutrition Sciences. 7 (4): 56-59.

\section{How to cite this article:}

Yao Paul ATTIEN, Arthur Constant ZEBRE, Haziz SINA, Djédoux Maxime ANGAMAN, Lamine BABA MOUSSA and Adjehi T. DADIE. 2021. Assessment of the Sanitary Quality of the Dishes Sold in Street's Restaurants with High Frequentation in Daloa (Ivory Coast). Int.J.Curr.Microbiol.App.Sci. 10(12): 206-215. doi: https://doi.org/10.20546/ijcmas.2021.1012.024 